\title{
Farklı Biçim Yüksekliği ve Sayısının Arpanın Ot ve Tohum Verimine Etkileri
}

\author{
Ahmet Gökkuşs ${ }^{1}$ Furat Alatürk ${ }^{1}$ Buse Kıran $^{1}$ Elif Kırmızıü̈l $^{{ }^{*}}$ Baboo Ali $^{1}$ Mehmet Eroğuz $^{1}$ \\ Halilcan Acet ${ }^{1}$
}

${ }^{1}$ ÇOMÜ Ziraat Fakültesi, Tarla Bitkileri Bölümü. 17100/Çanakkale

*Sorumlu yazar: elifkrmzgl@gmail.com

Geliş Tarihi: 12.07.2018

Kabul Tarihi: 06.12.2018

$\ddot{O} z$

$\mathrm{Bu}$ araştırma, arpanın tohum üretimi ile birlikte ot üretiminin de mümkün olabilirliğini belirlemek amacıyla 2016-2017 yetiştirme döneminde ÇOMÜ Ziraat Fakültesi Dardanos Yerleşkesi deneme alanında yürütülmüştür. Araştırmada bitkiler farklı yüksekliklere $(20,30$ ve $40 \mathrm{~cm})$ ulaştıklarında $5 \mathrm{~cm}$ yükseklikten biçilmiştir. Denemede ayrıca biçim sayıları $(0,1,2,3$ ve 4 kez biçim) da faktör olarak ele alınmıştır. Tesadüf blokları deneme desenine göre 3 tekerrürlü olarak kurulan denemede, yeşil ve kuru ot verimleri, otun ham protein, NDF ve ADF oranları ile tohum verimleri ele alınmıştır. Denemeden elde edilen verilere göre, biçim sayısı ve biçim yüksekliğinin (BY) artışına bağlı olarak yeşil ve kuru ot verimlerinde artış, tohum veriminde ise azalma olmuştur. Bir biçim yapılan uygulamalarda tohum verimi ortalama $\% 13,4,4$ biçimde ise $\% 51,4$ azalmıştır. Bunun yanında biçim sayısı ve BY'ndeki artışına bağlı olarak otun ham protein oranı azalmış, ham kül, NDF ve ADF içerikleri önemli oranda değişmemiştir. Sonuç olarak, denemede uygulandiğı şekliyle tane verimi düşürmeden ot elde etmek mümkün görülmemektedir. Bu sonucun alınmasında biçimin $5 \mathrm{~cm}$ anız kalacak şekilde yapılması bir etken olabilir. Bu nedenle ikili üretimin olabilirliğini daha iyi ortaya koyabilmek için, daha yüksek anız bırakılacak şekilde yeni araştırmaların planlanmasında yarar görülmüştür.

Anahtar Kelimeler: Arpa, biçim yüksekliği, biçim sayısı, ot verimi, tohum verimi, ham protein oranı.

\section{The Effects of Different Harvest Heights and Numbers on Hay and Seed Yield of Barley Abstract}

This research has been conducted in the experimental trail area of the Faculty of Agriculture, Dardanos Campus of Çanakkale Onsekiz Mart University, during the sowing season of 2016-2017 in order to determine the possibility of hay production along with the seed production of barley crop. In the research, the plants have been harvested from $5 \mathrm{~cm}$ height when they reached different heights $(20,30$ and $40 \mathrm{~cm})$. The numbers of harvest $(0,1,2,3$ and 4 times reaping) are also considered as factors in the experiment. The yields of hay and green fodder, ratios of pure protein, NDF and ADF of the hay, and seed yields were also taken in hand according to established experiment of randomized complete block design using 3 replications. According to the obtained data from experiment, an increase in green and dry fodder, while a decrease in seed yield found depending on increasing in number and height of harvesting. The seed yield decreased by an average of $18 \%$ in the experiments with single harvesting, while $59 \%$ decrease has been observed with 4 harvestings. However, the ratio of pure protein in hay decreased and the content of NDF increased due to the increase in number and height of harvesting. As a result, it is not possible to obtain hay without lowering the yield of grain as applied in the experiment. There could be an impact for obtaining this result if the harvesting would be done by leaving $5 \mathrm{~cm}$ stubble into the experimental trials. Consequently, it has been found beneficial to plan new researches by leaving higher stubble in order to better demonstrate the feasibility of dual production.

Keywords: Barley, Harvest height, Harvest number, Hay yield, Pure protein ratio, NDF ratio.

\section{Giriş}

Hayvan besleme açısından kaba yem en temel kaynak (Pond ve ark., 1995) olup, hayvanın fizyolojisi açısından hayati önem taşımaktadır (Van Soest, 1983). Hayvan beslemede kullanılan kaba yemin en az $\% 7$ oranında ham protein içeresi gerekmektedir (Meen, 2001). Tahıl otunun ham protein içeriği bu seviyenin çok üzerindedir. Fakat ot için hasat zamanı geciktikçe protein oranları da \%4'e kadar düşmektedir (Twidwell ve ark., 1987; Hasar ve Tükel, 1994; Tan, 1995). Selüloz rumen çalışması ve rumende süt yağı üretimi için önemlidir ve kaba yemlerde en fazla \%32 oranında bulunması istenmektedir (Kılıç, 1985). Fakat tahıllarda olgunlaşmayı geciktirdiğimiz takdirde selüloz oranı bu seviyenin üstüne çıkabilmektedir (Klebesadel, 1969; Tan, 1995). Tahıl otunun sindirilme 
oranı yeşil dönemde iken \%50'nin üzerinde olmasına rağmen (Kilcher ve Troelsen, 1973), baklagillere nazaran sindirilebilir organik madde ve sindirilebilir kuru madde oranı daha düşük seviyelerdedir (Twidwell ve ark., 1987; Droushiotis, 1989; Moreira, 1989). İçerdikleri ADL oranının düşük olmasından dolayı (Tan ve Serin, 1997), arpa ve tritikalenin sindirilme oranı buğday ve çavdara nazaran daha yüksektir (Cherney ve Marten, 1982; Droushiotis, 1989). Hayvan beslemede gerekli olan makro elementlerin en düşük seviyeleri $\% 0,8 \mathrm{~K}, \% 0,3 \mathrm{Ca}, \% 0,2 \mathrm{P}$ ve $\% 0,1 \mathrm{Mg}$ olmalıdır (Anon., 1965 , 1971). Bu verilere göre buğday, arpa, yulaf ve tritikale sadece Mg bakımından yetersiz düzeydedir (Tingle ve Dawley, 1972; Droushiotis, 1989; Korkmaz ve ark., 1993; Tan, 1995). Fakat arpa bu bakımından tahıllar içeresinde en iyi durumdadır. Potasyum oranı \%2'nin üzerinde (Mayland ve ark., 1976; Korkmaz ve ark., 1993) ve Ca ve Mg bakımından da yeterli düzeydedir (Tingle ve Daley, 1972).

Türkiye'de hayvancıllı̆ı̆ en önemli sorunlarının başında nitelikli ve yeterli kaba yemin olmaması gelmektedir. Bunun nedenleri arasında çayır ve meraların uygun şekilde kullanılmaması ve yem bitkileri ekim alanının az bulunmaktadır. Bu sorunun giderilmesi amaciyla son yıllarda baklagil ve buğdaygil yem bitkilerinin saf ve karışık ekimlerinden oluşan yapay mera tesislerinin kurulması hız kazanmıştır (Genç, 2011). Bu nedenle biçim/otlatmadan sonra yeniden büyüme özelliğine sahip tahıl meraları gibi kısa süreli yapay meralar oluşturularak kaba yem açığını kapatmak ve diğer yem kaynakları üzerindeki otlatma baskısını azaltmak birçok araştırmacı tarafından önerilmektedir (Gökkuş ve ark., 2005; Ouédraogo-Koné ve ark., 2006). Tahıllar dünyada en çok kültürü yapılan bitki grudur. Uyum yeteneğinin yüksek olması dünyanın pek çok yerinde yetiştirilmesine olanak sağlamıştır. Geniş alanlarda kültürü yapılmasının diğer bir nedeni ise hem insan hem de hayvan beslenmesinde kullanılıyor olmasıdır. Bununla beraber tuzlu topraklarda yetişebilmesi (arpa) ve çimlenmeden sonra hızlı gelişme göstermesi de önemli özelliklerine dahil edilebilir (Tan ve Serin, 1997). Tahıllar hem biçilerek hem de hasıl olarak otlatılmak suretiyle kaba yem ihtiyacını karşılamaktadır. Özellikle başaklanmadan önceki dönemlerinde karbonhidrat ve sindirilebilme oranları oldukça yüksek seviyededir (Baytekin ve ark., 2005). Kışlık ekilen buğday merasının hızlı büyüme ve soğuklara karşı dayanımı nedeniyle ilkbaharda doğal meradan yaklaşık 1 ay önce otlatma olgunluğuna ulaşmakta (Krenzer, 1994; Gökkuş ve Hakyemez, 2001) ve süt keçiciliğinde önemli bir yer teşkil etmektedir (Gökkuş ve ark., 2005). Böyle meralar ilkbahar ve kış soğuklarına karşı dayanıklı olup, tane ve yeşil ot üretmek amaciyla yetiştirilebilmektedir (Pinchak ve ark., 1989). Tahılların kaba yem olarak kullanımında en büyük dezavantajı yaprak/sap oranının az olması ve çabuk olgunlaştığı için besleme değerinin de düşük olmasıdır (Tan ve Serin, 1997). Arpa bu bitkiler içerisinde oldukça önemli bir yere sahiptir. Bu bitki daha çok yarı-kurak bölgelerde kullanılmakta olup, tuzlu topraklara da dayanıklıdır. Otunun sindirilebilir kuru maddesi ve sindirilebilir enerji değeri yüksektir (Joyce ve ark., 1971).

Bu nedenle bu çalışma, alternatif kaba yem kaynağı oluşturmak için tohum üretmek amaciyla yetiştirilen arpada, tohum verimini fazlaca düşürmemek kaydiyla ot üretiminin mümkün olup olamayacağını ve en kârlı yetiştiricilik biçimini ortaya koymak amacıyla yürütülmüsștür.

\section{Materyal ve Yöntem}

Araştırma 2016-2017 yetiştirme döneminde ÇOMÜ Dardanos Yerleşkesindeki deneme alanında yürütülmüştür. Denemenin yapıldığı dönemde uzun yılların (1928-2016) aylık ortalama sicaklığ $15,0{ }^{\circ} \mathrm{C}$ iken, 2017 yılı Ocak-Ekim arası ise ortalama sicaklık $17,0^{\circ} \mathrm{C}$ 'dir. Uzun y1llara (19282016) ait toplam yağış 616,2 mm iken, denemenin yürütüldüğü dönemde (2017-Ocak-Ekim) ise 467,7 mm olmuştur (Anonim, 2018). Deneme alanı toprakları killi-tınlı bünyeye sahip olup, orta kireçli, N ve $\mathrm{P}$ bakımından yetersiz, $\mathrm{K}$ bakımından yeterli ve organik maddece fakirdir.

Bitki materyali olarak arpanın Bolayır çeșidi kullanılmıștır. Araștırma tesadüf blokları deneme desenine göre 3 tekerrürlü olarak kurulmuştur. Denemede parsel genişliği $1 \mathrm{~m}$, parsel uzunluğu $5 \mathrm{~m}$, toplam parsel alan $15 \mathrm{~m}^{2}$, parseller arası $0,5 \mathrm{~m}$ ve bloklar arası ise $1 \mathrm{~m}$ olacak şekilde tanzim edilmiştir. Araştırmada faktör olarak biçim sayısı (kontrol, 1, 2, 3 ve 4 kez biçim) ve biçimdeki bitki boyu $(20,30$ ve $40 \mathrm{~cm}$ ) ele alınmıştır. Biçimler $5 \mathrm{~cm}$ anız kalacak şekilde yapılmıştır. Denemede sulama yapılmamış ve yabancı otlar elle yok edilmiştir. Araştırmada $20 \mathrm{~kg} / \mathrm{da}$ olacak şekilde ekim öncesinde DAP (diamonyum fosfat) gübresi atılmıştır. Ot hasatları Nisan ve Mayıs aylarında, tohum hasadı ise Haziran sonu-Temmuz başında yapılmıştır. Araştırmada ot ve tohum verimi, ham protein (HP), ham kül (HK), NDF, ADF oranları incelenmiştir. HP ve HK analizleri AOAC (1990)'a göre, NDF ve ADF 
analizleri ise Van Soest ve ark. (1991)'na göre yapılmıștır. Denemeden elde edilen veriler tesadüf blokları deneme desenine göre JMP 11 istatistik paket programı kullanılarak istatistik analize tabi tutulmuştur.

\section{Bulgular ve Tartışma \\ Ot Verimi}

Farklı uygulamalara göre elde edilen toplam yeşil ve kuru ot verimleri sadece biçim sayılarına göre önemli bulunmuştur (Çizelge 1). Biçim sayısı azaldıkça yeşil ve kuru ot verimleri önemli oranda azalmıştır. En yüksek toplam yeşil ve kuru ot verimleri (1607,1 ve 397,0 kg/da) 4 kez biçilen parsellerden elde edilmiştir. Bir biçim yapılan parsellerin ortalama yeşil ve kuru ot verimleri de sırasıyla 758,3 ve $175,0 \mathrm{~kg} / \mathrm{da}$ olarak belirlenmiştir. Biçim yüksekliklerine göre parsellerin yeşil ot verimleri 1077,6-1207,9 kg/da, kuru ot verimleri de 256,7-276,3 kg/da arasında değişim göstermiștir. $40 \mathrm{~cm}$ boya ulaştıktan sonra biçilen bitkilerde ot verimleri biraz daha yüksek olsa da, bu istatistiki olarak önemli bulunmamıştır.

Çizelge 1. Farklı biçim yüksekliği ve sayılarına göre arpanın yeşil ve kuru ot verimleri $(\mathrm{kg} / \mathrm{da})$

\begin{tabular}{|c|c|c|c|c|}
\hline \multirow{2}{*}{ Biçim sayısı } & \multicolumn{3}{|c|}{ Biçim Yüksekliği } & \multirow{2}{*}{ Ortalama } \\
\hline & $20 \mathrm{~cm}$ & $30 \mathrm{~cm}$ & $40 \mathrm{~cm}$ & \\
\hline \multicolumn{5}{|c|}{ Yeşil Ot Verimi } \\
\hline 1 & 852,9 & 586,7 & 836,4 & $758,3 \mathbf{c}$ \\
\hline 2 & 1026,0 & 1078,0 & 1087,5 & $1063,9 \mathbf{b}$ \\
\hline 3 & 1073,4 & 1057,8 & 1084,4 & $1071,8 \mathbf{b}$ \\
\hline 4 & 1358,1 & 1639,4 & 1823,7 & $1607,1 \mathbf{a}$ \\
\hline Ortalama & 1077,6 & 1090,2 & 1207,9 & \\
\hline Önemlilik: & \multicolumn{4}{|c|}{$\mathrm{P}_{\mathrm{BY}}=0,4176 \mathrm{P}_{\mathrm{BS}}<0,0001, \mathrm{P}_{\mathrm{BY} * \mathrm{BS}}=0,5453$} \\
\hline \multicolumn{5}{|c|}{ Kuru Ot Verimi } \\
\hline 1 & 184,9 & 160,3 & 179,9 & $175,0 \mathbf{c}$ \\
\hline 2 & 229,4 & 237,8 & 226,3 & $231,7 \mathbf{b}$ \\
\hline 3 & 278,5 & 241,1 & 253,5 & $257,7 \mathbf{b}$ \\
\hline 4 & 334,1 & 411,6 & 445,4 & $397,0 \mathbf{a}$ \\
\hline Ortalama & 256,7 & 262,7 & 276,3 & \\
\hline Önemlilik: & $\mathrm{P}_{\mathrm{BY}}=0,6907 \mathrm{I}$ & $\mathrm{P}_{\mathrm{BY} * \mathrm{BS}}=$ & & \\
\hline
\end{tabular}

Yeşil ot ve kuru ot verimleri biçim yüksekliklerine göre önemli değişim göstermez iken, biçim sayısının artışına bağlı olarak önemli oranda artmıştır. Bu artış verim ile ilgili olmayıp, sadece biçim sayısının fazla olmasından ileri gelmiştir. Çünkü en yüksek verimler ilk biçimlerden elde edilmiş, fakat toplamda en fazla verimler ise $4 \mathrm{kez}$ biçilen parsellerden üretilmiștir (Şekil 1 ve 2). Arpa ile yapılan bir çalışmada ot verimleri biçim yüksekliklerine göre önemli oranda değişmez iken, biçim sayısının artışına bağlı olarak her biçimden elde edilen ortalama ot verimleri ise düşmüştür (Gökkuş ve ark., 2017). Bunun nedeni her biçimden sonra bitkilerin yeniden büyüme ve üretim kapasitelerinin giderek düşmesinden ileri gelmektedir.

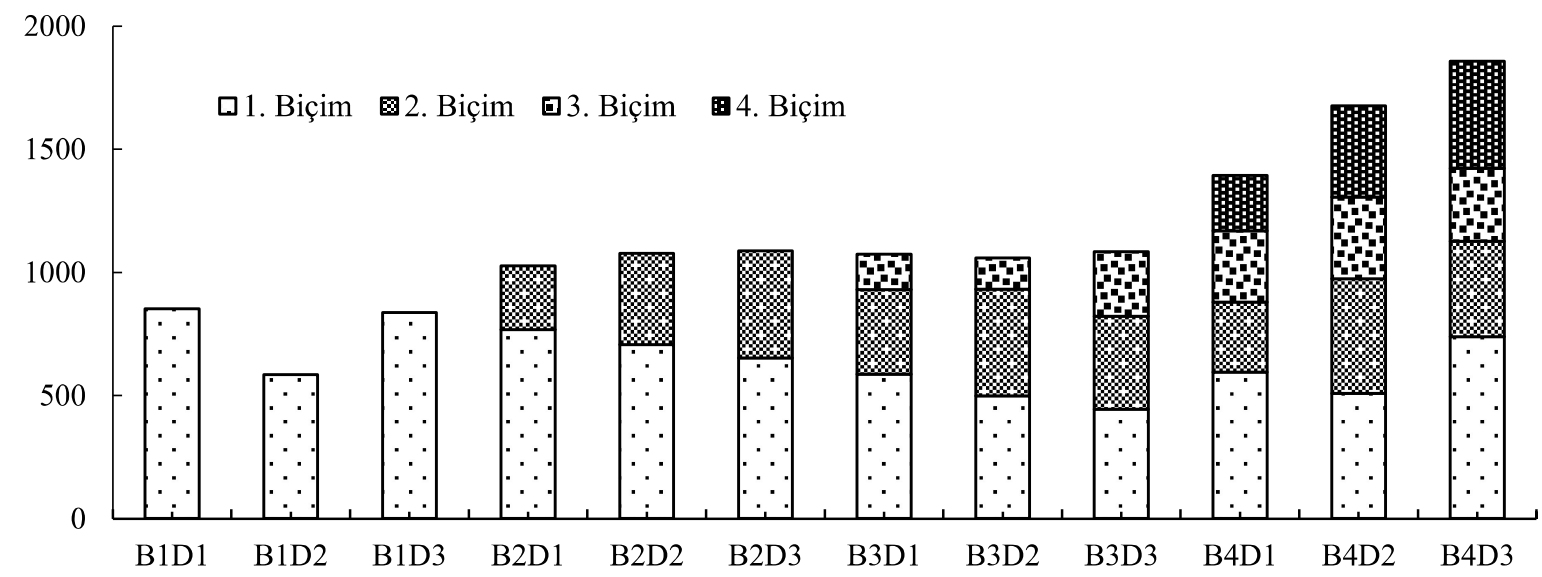

Şekil 1. Farklı biçim sayısı ve yüksekliklerine göre toplam yeşil ot verimleri $(\mathrm{kg} / \mathrm{da})$. 


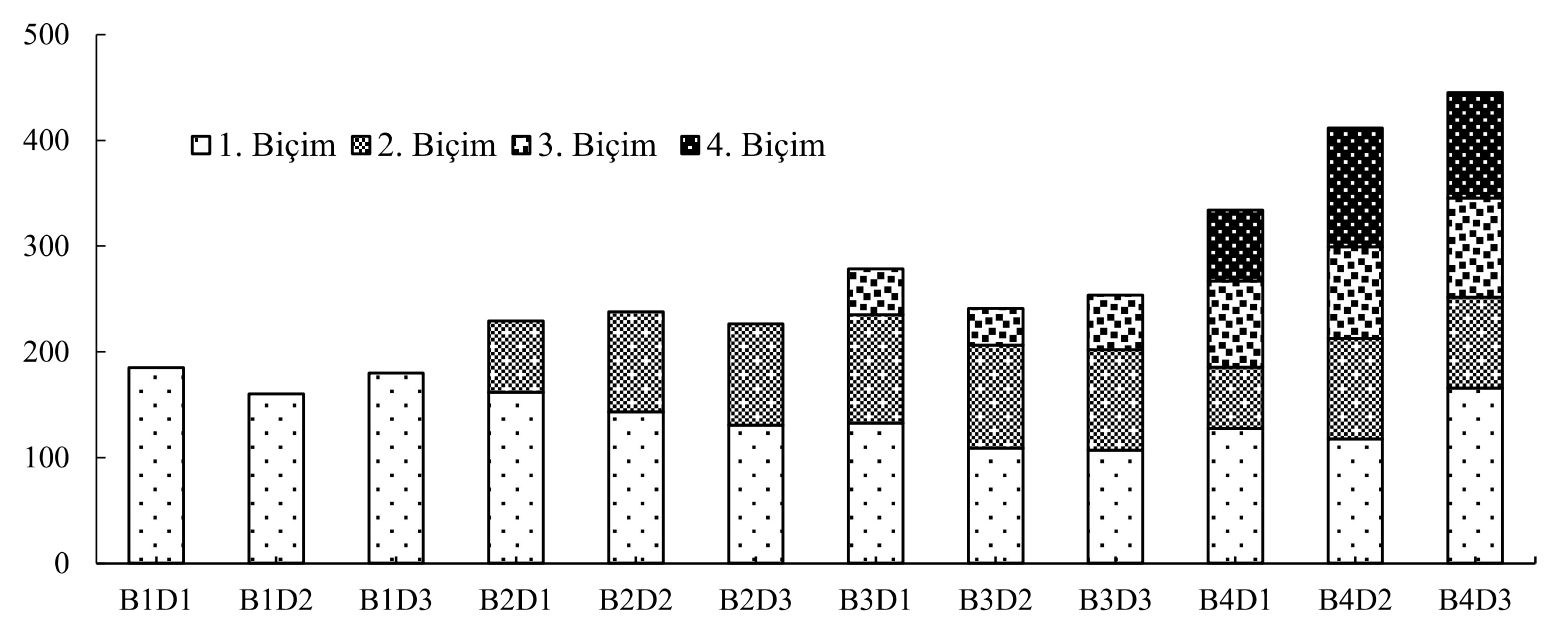

Şekil 2. Farklı biçim sayısı ve yüksekliklerine göre toplam kuru ot verimleri (kg/da).

\section{Tohum Verimi}

Farklı biçim uygulamalarına göre elde edilen tohum verimleri sadece biçim sayılarına göre istatistiki olarak önemli olurken $(\mathrm{P}<0,0001)$, biçim yüksekliği ve biçim sayısı*biçim yüksekliği etkileşimi önemsiz bulunmuştur. Biçim sayısının artışına bağlı olarak tohum veriminde azalma olmuştur. En yüksek tohum verimi $(457,9 \mathrm{~kg} / \mathrm{da}$ ) biçilmeyen (kontrol) parselinde elde edilmiştir. Bunu azalan sırayla bir $(369,6 \mathrm{~kg} / \mathrm{da})$ ve iki $(314,3 \mathrm{~kg} / \mathrm{da})$ biçim yapılan parsellerin tohum verimleri izlemiştir. En düşük verimler (222,6 ve $267,7 \mathrm{~kg} / \mathrm{da}) 4$ ve $3 \mathrm{kez}$ biçilen parsellerde alınmıştır. Biçim yüksekliğine göre parsellerin tohum verimleri 305,4-346,2 kg/da arasında değişmiştir. Önemsiz olmakla birlikte biçimdeki bitki boyu arttıkça tohum verimi de azalmıştır (Çizelge 3).

Çizelge 3. Farklı biçim yüksekliği ve sayılarına göre arpanın tohum verimleri (kg/da)

\begin{tabular}{ccccc}
\hline \multirow{2}{*}{ Biçim sayısı } & \multicolumn{3}{c}{ Biçim Yüksekliği } & \multirow{2}{*}{ Ortalama } \\
\cline { 2 - 4 } & $\mathbf{2 0} \mathbf{~ c m}$ & $\mathbf{3 0} \mathbf{~ c m}$ & $\mathbf{4 0} \mathbf{~ c m}$ & \\
\hline $\mathbf{0}$ & 470,3 & 462,0 & 441,3 & $457,9 \mathbf{a}$ \\
$\mathbf{1}$ & 404,7 & 357,0 & 347,0 & $369,6 \mathbf{b}$ \\
$\mathbf{2}$ & 335,7 & 312,0 & 295,3 & $314,3 \mathbf{c}$ \\
$\mathbf{3}$ & 280,3 & 274,0 & 248,7 & $267,7 \mathbf{d}$ \\
$\mathbf{4}$ & 240,0 & 233,0 & 194,7 & $222,6 \mathbf{d}$ \\
\hline Ortalama & 346,2 & 327,6 & 305,4 & \\
\hline Önemlilik: & $\mathrm{P}_{\mathrm{BY}}=0,0738, \mathrm{P}_{\mathrm{BS}}<0,0001, \mathrm{P}_{\mathrm{BY} * \mathrm{BS}}=0,9974$ \\
\hline
\end{tabular}

Biçim sayısı arttıkça tohum verimindeki azalma, bitkilerin her biçimden sonra verim ve üretim güçlerinin azalmasından kaynaklanmaktadır. Farklı buğdaygillerle yapılan diğer çalışmalarda da biçim sayısının artışına bağlı olarak tohum verimlerinin de düștüğü tespit edilmiştir (Sağlamtimur ve ark., 1986; Çelen, 1991; Özdil, 1996; Kuşvuran ve Tansı, 2005).

\section{Ham Protein Oranı}

Yapılan varyans analize göre, ortalama ham protein (HP) oranları biçim yüksekliği $(\mathrm{P}=$ $0,8634)$ ve biçim yüksekliği*biçim sayısı etkileşiminde $(\mathrm{P}=0,8542)$ önemsiz olurken, biçim sayısına göre önemli $(\mathrm{P}=0,0273)$ bulunmuştur (Çizelge 4$)$. HP oranları biçim yüksekliğinin artışına bağlı olarak önemsiz oranda azalmıștır. En yüksek HP oranı \%27,93 ile $20 \mathrm{~cm}$ yükseklikte biçilen bitkilerde elde edilirken, bunu \%26,82 ile $40 \mathrm{~cm}$ ve $\% 26,6030 \mathrm{~cm}$ yükseklikten biçilen izlemiştir. Biçim sayısının artışına bağlı olarak HP oranlarında düşüş olmuştur. En yüksek HP oranı 1 kez biçilen parsellerde $(\% 27,03)$ belirlenirken, en az HP oranları 3, 4 ve 2 kez biçilen parsellerin otunda $(\% 24,35$, 24,39 ve 25,99 ) tespit edilmiştir (Çizelge 4).

Genel olarak HP oranları biçim sayılarının artışına bağlı olarak azalmıştır. Bunun temel nedeni büyümenin ilerlemesine ve hava sıcaklıkların artışına bağlı olarak bitkinin generatif döneme geçme isteğidir. Bunun sonucunda bitkide yaprak/sap oranı ile yeşil doku oranı azalarak bitki kartlaşmıştır 
(Miller, 1984). Bununla beraber olgunlaşmanın ilerlemesine bağlı olarak bitki bünyesinde bulunan çeper maddelerinde artış da HP oranında düşüşe yol açmaktadır (Haddi ve ark., 2003; Kaya, 2008; Aydoğan ve ark., 2014). Nitekim Çanakkale yöresinde kurulan arpa meralarında bırakılan anız yüksekliğine bağlı olarak biçim sayısı arttıkça HP oranında azalma olduğu belirtilmiştir (Gökkuş ve ark., 2017). Bunun yanında arpa, yulaf ve tritikale ile yapılan çalışmada, olgunlaşmanın ilerlemesine bağlı olarak otun HP içeriğinde azalma kaydedilmiştir (Khorasani ve ark., 1997). Benzer şekilde arpa, buğday, çavdar, yulaf ve tritikale ile yapılan araştırmada (Coşkun ve ark., 2014), büyümenin ilerlemesine bağlı olarak otun HP içeriklerinde \%42 oranında düşüşler olduğu vurgulanmıştır.

\section{Ham Kül Oranı}

Arpa otunun ham kül $(\mathrm{HK})$ içeriği üzerinde biçim yüksekliği $(\mathrm{P}=0,1372)$, biçim sayısı $(\mathrm{P}=$ $0,2156)$ ve biçim yüksekliği*biçim sayıları etkileşimi $(\mathrm{P}=0,7774)$ istatistiki olarak önemli olmamıştır (Çizelge 4).

Ortalama HK içeriği biçim yüksekliğinin artışına bağlı olarak önemsiz oranda azalmıştır. En yüksek HK oranı \%13,18 ile $20 \mathrm{~cm}$ yükseklikten biçilen parsellerde belirlenirken, en düşük oran $\% 10,20$ ile $30 \mathrm{~cm}$ yükseklikte biçilen parsellerde tespit edilmiştir. Biçim sayısını artışına bağlı olarak HK oranı düzensiz olarak değişim göstermiştir. Buna göre HK oranları \%9,77-13,44 arasında değişim göstermiştir (Çizelge 4).

Çizelge 4. Farklı biçim yüksekliği ve sayılarına göre arpa otunun ham protein ve ham kül oranları (\%)

\begin{tabular}{|c|c|c|c|c|}
\hline \multirow{2}{*}{ Biçim sayısı } & \multicolumn{3}{|c|}{ Biçim Yüksekliği } & \multirow{2}{*}{ Ortalama } \\
\hline & $20 \mathrm{~cm}$ & $30 \mathrm{~cm}$ & $40 \mathrm{~cm}$ & \\
\hline \multicolumn{5}{|c|}{ Ham Protein Oranı } \\
\hline 1 & 27,93 & 26,35 & 26,82 & $27,03 \mathbf{a}$ \\
\hline 2 & 25,74 & 26,60 & 25,62 & $25,99 \mathbf{a b}$ \\
\hline 3 & 24,00 & 25,19 & 23,85 & $24,35 \mathbf{b}$ \\
\hline 4 & 24,95 & 23,72 & 24,50 & $24,39 \mathbf{b}$ \\
\hline Ortalama & 25,65 & 25,47 & 25,20 & \\
\hline \multirow{2}{*}{\multicolumn{5}{|c|}{$\frac{\mathrm{P}_{\mathrm{BY}}=0,8634 \mathrm{P}_{\mathrm{BS}}=0,0273, \mathrm{P}_{\mathrm{BY} * \mathrm{BS}_{\mathrm{B}}=0,8542}}{\text { Ham Kül Oranı }}$}} \\
\hline & & & & \\
\hline 1 & 11,27 & 11,81 & 11,28 & 11,45 \\
\hline 2 & 13,70 & 9,33 & 11,14 & 11,39 \\
\hline 3 & 10,73 & 8,21 & 10,39 & 9,77 \\
\hline 4 & 17,02 & 11,44 & 11,86 & 13,44 \\
\hline Ortalama & 13,18 & 10,20 & 11,17 & \\
\hline Önemlilik: & \multicolumn{4}{|c|}{$\mathrm{P}_{\mathrm{BY}}=0,1372, \mathrm{P}_{\mathrm{BS}}=0,2156, \mathrm{P}_{\mathrm{BY} * \mathrm{BS}}=0,7774$} \\
\hline
\end{tabular}

\section{NDF ve ADF Oranları}

Arpa otunun NDF ve ADF oranları biçim yüksekliği $(\mathrm{P}=0,8666$ ve 0,6536$)$, biçim sayısı $(\mathrm{P}=$ $0,9047$ ve 0,1946$)$ ve biçim yüksekliği*biçim sayısı etkileşiminde $(\mathrm{P}=0,8975$ ve 0,5381$)$ istatistiki olarak önemli olmamıştır. Biçimdeki bitki boyuna göre ortalama NDF oranları \%48,00-48,57 ve ADF oranları \%35,94-36,56; biçim sayılarına göre de NDF içeriği \%47,79-48,75 ve ADF içeriği \%35,4937,02 arasında değişmiştir. (Çizelge 5).

Biçimdeki bitki yüksekliklerine göre çeper bileșenleri arasında önemli farklılıkların ortaya çıkmaması, muhtemelen bitkilerde hızlı vejetatif büyüme sürecine rastlayan bu dönemde çeper kalınlaşmasından ziyade yeni hücrelerin oluşumu ve genişlemesi ile boy artışının gerçekleşmesinden ileri gelmiştir. Biçim sayılarına bağlı olarak NDF ve ADF oranlarında önemli farklılığın çıkmaması, bütün biçimlerde ilk biçimlerin sapa kalkma ortalarında yapılması ve çok biçimli uygulamalarda ise her biçimden sonra bitkilerin yeni vejetatif dokular olușturmaları sonucu bütün bitki örneklerinin körpe vejetatif dokulara sahip olmalarının etkili olduğu ifade edilebilir. 
Çizelge 5. Farklı biçim yüksekliği ve sayılarına göre arpa otunun NDF ve ADF oranları (\%)

\begin{tabular}{|c|c|c|c|c|}
\hline \multirow{2}{*}{ Biçim sayısı } & \multicolumn{3}{|c|}{ Biçim Yüksekliği } & \multirow{2}{*}{ Ortalama } \\
\hline & $20 \mathrm{~cm}$ & $30 \mathrm{~cm}$ & $40 \mathrm{~cm}$ & \\
\hline \multicolumn{5}{|c|}{ NDF Oranı } \\
\hline 1 & 48,02 & 49,66 & 48,56 & 48,75 \\
\hline 2 & 48,89 & 46,61 & 47,86 & 47,79 \\
\hline 3 & 48,55 & 47,07 & 49,36 & 48,33 \\
\hline 4 & 48,42 & 48,65 & 48,49 & 48,52 \\
\hline Ortalama & 48,47 & 48,00 & 48,57 & \\
\hline Önemlilik: & \multicolumn{4}{|c|}{$\mathrm{P}_{\mathrm{BY}}=0,8666, \mathrm{P}_{\mathrm{BS}}=0,9047, \mathrm{P}_{\mathrm{BY} * \mathrm{BS}}=0,8975$} \\
\hline \multicolumn{5}{|c|}{ ADF Oranı } \\
\hline 1 & 36,16 & 37,44 & 35,29 & 36,30 \\
\hline 2 & 37,16 & 36,36 & 37,54 & 37,02 \\
\hline 3 & 35,90 & 35,39 & 37,44 & 36,24 \\
\hline 4 & 35,66 & 34,56 & 35,96 & 35,49 \\
\hline Ortalama & 36,29 & 35,94 & 36,56 & \\
\hline Önemlilik: & $\mathrm{P}_{\mathrm{BY}}=0,6536$ & $\mathrm{P}_{\mathrm{BY} * \mathrm{BS}}=$ & & \\
\hline
\end{tabular}

\section{Ekonomik Değerlendirme}

Arpa bitkilerinden hasat edilen ot ve tohum miktarlar1 Biga Ticaret Borsas1 201.11.2017 tarihindeki fiyatları dikkate alınarak ekonomik bir değerlendirmeye tabi tutulmuş ve sonuçlar Çizelge 6'da sunulmuştur (Anonim, 2017). Günün şartlarında ot fiyatlarının tohum fiyatlarından yüksek olması, ot üretiminin yüksek olduğu çok biçimli uygulamalarda kârlılığın da yüksek olmasına sebep olmuştur. Buna göre biçim sayısının artışına bağlı olarak toplam ot üretimi de arttığı için elde edilen kâr oranı da yükselmiștir. Kontrol parselinde toplam 373,2 TL/da gelir elde edilirken, bu rakam 1 biçimde 458,7 TL/da, 2 biçimde 464,7 TL/da, 3 biçimde 450,1 TL/da ve 4 biçimde 538,7 TL/da olarak hesaplanmıştır. Dört biçimli uygulama sonucunda kontrole göre $\% 65,5$ daha fazla gelir sağlanmıştır. Ancak genellikle tohum fiyatlarının ot fiyatlarından daha yüksek olduğu yıllarda bu sonuçların alınamayacağı gözden kaçmamalıdır.

Çizelge 6. Biçim sayılarına göre ortaya çıkan ot ve tohum fiyatlarına (TL) göre ekonomik değerlendirme

\begin{tabular}{ccccc}
\hline Biçim sayısı & Tohum geliri & Ot geliri & Toplam gelir & Tohuma göre fark \\
\hline Kontrol & 373,2 & - & 373,2 & - \\
$\mathbf{1}$ & 301,2 & 157,5 & 458,7 & $+85,5$ \\
$\mathbf{2}$ & 256,2 & 208,5 & 464,7 & $+91,5$ \\
$\mathbf{3}$ & 218,2 & 231,9 & 450,1 & $+76,9$ \\
$\mathbf{4}$ & 181,4 & 357,3 & 538,7 & $+165,5$ \\
\hline
\end{tabular}

Not: Çizelgedeki hesaplamalar Biga Ticaret Borsası 20.11.2017 tarihli fiyatları esas alınarak, otun fiyatı 0,90 TL/kg ve tohumun fiyatı ise $0,815 \mathrm{TL} / \mathrm{kg}$ olmak üzere yapılmıştır.

\section{Sonuç ve Öneriler}

Kaliteli kaba yem kaynaklarının başında gelen çayır-meralar ile yem bitkilerinden elde edilen kaba yemler ülkemiz hayvancılığ 1 açısından yetersiz durumdadır. Bu yetersizliği gidermek amaciyla son yıllarda tahıllar ile oluşturulan yapay meralar ve hasıl olarak tahılların biçerek değerlendirilmesi oldukça önem kazanmıştır. Bunun yanında tahıllarda tohum üretimi yanında, karlılığı azaltmayacak şekilde ot üretiminin de mümkün olabileceğine dair çalışmalar da önem kazanmaktadır. Bu amaçla bu çalışmada da tohum üretimi yapmak amacıyla ekilen arpa alanlarının erken ilkbahar döneminde farklı biçim yüksekliği ve farklı biçim sayılarına bağlı olarak alınabilecek otun verim ve kalitesi ile en sonunda elde edilecek tohum verimleri tespit edilmiştir. Bu amaçla 3 farklı biçim yüksekliği $(20,30$ ve $40 \mathrm{~cm}$ ) ve toplamda $4 \mathrm{kez}$ biçim araştırmada faktör olarak ele alınmıştır. Yapılan çalışmanın sonucunda biçimdeki bitki yüksekliklerinin ot verimlerine önemli etkisi olmazken, biçim sayılarına göre önemli artış olmuştur. Dört kez biçilen parsellerde yeşil ot verimi $1600 \mathrm{~kg} / \mathrm{da}$ 'a, kuru ot verimi ise $397,0 \mathrm{~kg} / \mathrm{da}$ 'a ulaşmıştır. Bununla beraber otun HP içeriği ilk biçilen parsellerde daha yüksek olurken, biçim sayısına bağlı olarak bu oranlar düşmüştür. Ayrıca otun HK, NDF ve ADF oranları 
biçim uygulamalarına bağlı olarak önemli değişim göstermemiştir. Ot üretimindeki artış ile tohum veriminde önemli azalma meydana gelmiştir. Örneğin bir kez biçilen parsellerden toplam $175,0 \mathrm{~kg} / \mathrm{da}$ ot elde edilirken, kontrol parseline göre tohum veriminde $\% 13,4$ azalma; 4 kez biçilen parsellerde ise $397,0 \mathrm{~kg} / \mathrm{da}$ ot üretimine karş111k \%51,4 tohum kaybı olmuştur. Fakat ekonomik değerlendirme sonucunda kontrol parselinde dekara 373,2 TL gelir elde edilirken, 4 biçim uygulamasında gelir 538,7 TL'ye yükselmiştir. Yapılan çalışmanın sonucunda, tohum üretimi amacıyla ekilen arpada erken ilkbaharda ot üretmek için de biçim yapılması günümüz piyasa şartlarında (otun tohumdan pahalı olması durumunda) daha çok maddi kazanç sağlamaktadır. Tohum fiyatlarının artması durumunda ise bu sonuçların elde edilmesi söz konusu olmayacaktır. Sonuç olarak, arpada tohum veriminden bir miktar fedakârlık ederek ot üretmek mümkün olabilecektir.

\section{Kaynaklar}

Anonim, 2017. Biga Ticaret Borsası. https://borsa.tobb.org.tr/fiyat_borsa.php?borsakod=5BI10.

Anonim, 2018. Çanakkale Meteoroloji Genel Müdürlüğ̈ü.

Anonymous, 1965. The Nutrient Requirements of Farm Livestock. No: 2. Ruminants, A.R.C. London, $164 \mathrm{p}$.

Anonymous, 1971. Nutrient Requirements of Beef Cattle. N.A.S. Washington, D.C. 55 p.

AOAC, 1990. Official Methods of Analysis (15th Ed.). Association of Official Analytical Chemists, Arlington, VA.

Aydoğan, S., Ișık, Ș., Şahin, M., Göçmen Akçacık, A., Hamzaoğlu, S., Doğan, Ş., Küçükcongar, M., Ateş, S., 2014. Farklı biçim zamanlarının yem bitkilerinin besin maddesi kompozisyonuna etkisi. Selçuk Tarım Bilimleri Dergisi. 1 (2): 45-49.

Baytekin, H., Yurtman, İ.Y., Savaş, T., 2005. Süt keçiciliğinde kaba yem üretim organizasyonu. Süt Keçiciliği Ulusal Kongresi, 26-27 Mayıs 2005, İzmir.

Çelen, A.E., 1991, Biçim zamanı ve yüksekliğinin İtalyan çimi (Lolium multiflorum var. westerwoldicum)'nin verim ve diğer bazı karakterlerine etkisi. Ege Üniversitesi Ziraat Fakültesi Dergisi, İzmir, 28 (2-3): 3136.

Cherney, J.H., Marten, G.C., 1982. Small grain crop forage potential: I. biological and chemical determinants of quality, and yield. Crop Sci. 22: 227-231

Coşkun, B., Keleş, G., İnal, F., Selçuk Alataş, M., Özcan, C., Ateş, S., 2014. Gebeleme ve hamur olum döneminde hasat edilen buğdaygil hasıllarının protein fraksiyonları ve ham protein üretimleri. Kafkas Uni. Vet. Fak. Dergisi. 20 (3): 457-460.

Droushiotis, D.N., 1989. Mixtures of annual legumes and small-grained cereals for forage production under low rainfall. J. Agric. Sci. 113: 249-253.

Genç, S., 2011. Keçi yetiștiriciliğinde doğal ve yapay meralardan yararlanma etkinliğinin arttırılması üzerine araştırmalar. ÇOMÜ Fen Bilimleri Enstitüsü Doktora Tezi. $100 \mathrm{~s}$.

Gökkuş, A., Birer, S., Alatürk, F., 2017. Farklı anız yükseklikleri kalacak şekilde yapılan biçimlerin arpanın ot verimi ve kalitesine etkileri. Türkiye 12. Tarla Bitkileri Kongresi, 12-15 Eylül 2017, Kahramanmaraş.

Gökkuş, A., Hakyemez, B.H., 2001. Buğdayın mera bitkisi olarak kullanımı ve önemi. Tarım ve Köy, Sayı: 139: 24-27.

Gökkuş, A., Hakyemez, B.H., Yurtman, İ.Y., Savaş, T., 2005. Farklı mera tiplerinde otlatma yoğunluklarının meranın ot verimi ve bitki kompozisyonu ile keçilerin verim ve davranışlarına etkileri (Kesin Rapor). TÜBİTAK, TOVAG, Proje No: VHAG-1884,55 s.

Haddi, M.L., Filacorda, S., Meniai, K., Rollin, F., Susmel, P., 2003. In Vitro fermentation kinetics of some halophyte shrubs sampled at three stages of maturity. Anim. Feed Sci. and Tech. 104: 215-225.

Hasar, E., Tukel, T., 1994. Çukurovanın taban koşullarında yetiştirilecek fiğ (Vicia sativa L.) + tritikale (Triticum x secale) karışımında karışım oranı ve biçim zamanının yem verimi ve kalitesi ile karışım öğelerinin tohum verimine etkisi üzerine araştırmalar. Tarla Bitkileri Kongresi, 25-29 Nisan 1994, İzmir, 104-106.

Joyce, J.P., Rattray, P.V., Parker, J., 1971. The utilization of pasture and barley by rabbits. I. feed intakes and live-weight gains. New Zealand Journal of Agric. Res. 14 (1): 173-179.

Kaya, Ş., 2008. Kaba yemlerin değerlendirilmesinde göreceli yem değeri ve göreceli kaba yem indeksi. Türk Bilimsel Derlemeler Derg. 1 (1): 59-64.

Khorasani, G.R., Jedel, P.E., Helm, J.H., Kennelly, J.J., 1997. Influence of stage of maturity on yield components and chemical composition of cereal grain silages. Can. J. Anim. Sci. 77: 259-267.

Kilcher, M.R., Troelsen, J.E., 1973. Contribution and nutritive value of the major plant components of oats through progressive stages of development. Can. J. Plant. Sci. 53: 251-256.

Kılıç, A., 1995. Hayvan Besleme, Öğretim, Öğrenim ve Uygulama Önerileri. TÜBİTAK Yay. No: 611, Veterinerlik ve Hayvancillk Grubu Seri No: 21, Ankara, 515 s. 
Korkmaz, A., Gülser, C., Manga, İ., Sancak, C., 1993. Samsun yöresinde yem bitkilerinden elde edilen otun mineral içeriğine ve kalitesine ekim sistemi ve biçim zamanlarının etkileri. Türk. Tar. ve Orm. Der. 17: 1069-1080.

Krenzer, G., 1994. Wheat for Pastures. Oklahoma State Univ. Coop. Ext. Serv., F-2586, 6 p.

Kuşvuran, A., Tansi, V., 2005. Çukurova koşullarında farklı biçim sayısı ve azot dozunun tek yıllık çim (Lolium multiflorum cv. Caramba) in ot ve tohum verimine etkisinin saptanması. Türkiye VI. Tarla Bitkileri Kongresi, 5-9 Eylül 2005, Antalya (Araştırma Sunusu Cilt II, Sayfa 797-802", Türkiye VI. Tarla Bitkileri Kongresi, ANTALYA, TÜRKIYE, 5-9 Ağustos 2005, cilt.2, ss.797-802

Mayland, H.F., Grunes, D.L., Lazar, V.A., 1976. Grass tetany hazard of cereal forages based upon chemical composition. Agron J. 68: 665-667.

Meen, A., 2001. Forage quality on the Arizona Strip. Rangelands, 23:7-12.

Miller, D.A., 1984. Forage crops. McGraw Hill Book Co., New York, N.Y.

Ouédraogo-Koné, S., Kaboré-Zoungrana, C.Y., Ledin, I., 2006. Behaviour of goats, sheep and cattle on natural pasture in the sub-humid zone of west Africa. Livestock Science. 105: 224-252.

Özdil, Ö., 1996. Çukurova koşullarında tek yıllık çimde (Lolium multiflorum L.) ekim zamanı ve tohumluk miktarının ot ve tohum verimi ile bazı karakterlerine etkisi. Yüksek Lisans Tezi, Ç.Ü., Fen Bilimleri Enstitüsü, Tarla Bitkileri Anabilim Dalı, Adana.

Pinchak, W.E., Hunt, L.J., Worral, W.D., Green, L.W., Caldwell, S.P., Worral, N.J., Hutcheson, D.P., 1989. Herbage production and nutritive value of small grain forages. Forage Research in Texas. 46-49.

Pond, W.G., Church, D.C., Pond, K.R., 1995. Basic Animal Nutrition and Feeding, Fourth Edition, John Wiley $\&$ Sons, New York, s. 615.

Sağlamtimur, T., Gülcan, H., Tükel, T, Tansı, V, Anlarsal, A. E., Hatipoğlu, R., 1986. Çukurova koşullarında yem bitkileri adaptasyon denemeleri 1: buğdaygil yem bitkileri. Ç. ̈̈. Ziraat Fakültesi Dergisi. 1 (3): $26-$ 37.

Tan, M., 1995. Fiğ + Tahıl Karışımları için en uygun karışım oranları ve biçim zamanlarının belirlenmesi. Doktora Tezi Atatürk Üniv. Fen Bil. Enst. Erzurum.

Tan, M., Serin, Y., 1997. Kaba yem olarak kullanılan tahılların besleme değerine yaklaşımlar. Atatürk Üni. Ziraat Fak. Derg. 28 (1): 130-137.

Tingle, J.N., Dawley, W.K., 1972. Mineral composition of whole-plant cereals for silage in Central British Columbia. Can. J. Plant. Sci. 52: 805-809.

Twidwell, A.K., Johnson, K.D., Cherney, J.H., Ohm, H.W., 1987. Forage yield and quality of soft red winter wheats and a winter triticale. Applied Agric. Res. 2: 84-88.

Van Soest, P.J., 1983. Nutritional Ecology of the Ruminant, O \& B Books Inc., s. 374.

Van Soest, P.J., Robertson, J.B., Lewis, B.A., 1991. Methods for dietary fiber, neutral detergent fiber, and nonstarch polysaccharides in relation to animal nutrition. J. Dairy Sci. 74, 3583-3597. 